\title{
The application of hierarchical teaching mode in College English Teaching
}

\author{
LI Zhaoying ${ }^{1, \text { a }}$ \\ ${ }^{1}$ Jilin Business and Technology College, Changchun 130000, China \\ aemail: lizhaoying@163.com
}

Keywords: Net test English; students; subjectivity; teaching

\begin{abstract}
Prominent to students as the main body thought, respect for individual differences, adjust measures to local conditions, individualized teaching is the theoretical basis of hierarchical teaching; prior to the implementation of the hierarchical teaching must carefully analyze the implementation of environmental background; implementation of the hierarchical teaching should be ready before the implementation of the preparation, to implement the objectives and requirements, teaching stratification of the basic aspects of the work; and in addition must also do a good job of stratified teaching effect test of summing up the work.
\end{abstract}

\section{Introduction}

New English curriculum standard pointed out: "the development of students is English course of the starting point and the home to return to, English course in goal setting, teaching process, curriculum evaluation and teaching resources development aspects are highlighted take the student as the main body of thought." In teaching, we must adhere to the students as the main idea, we must respect individual differences, according to local conditions, the implementation of human.

After entering the new century, the process of social information has been accelerating, people's educational ideas are changing rapidly, accordingly, the theory of educational and teaching research is also undergoing profound changes. In different stages of development of educational media technology, the education sector will have a different focus. That is to say, the development of information technology will bring about the reform of the teaching mode and learning method. Yuan Zhenguo 2002:182 once pointed out that, from the point of view of China and the world, since the beginning of the 21 st century, occurred in the education research in a profound shift in, transfer of information technology education research is one of them, people pay more and more attention to is "information technology rapid development under the background of education development and reform". The application of modern media technology in the field of education and teaching, the development of education is bound to play a great role in promoting. This effect will relates to the improvement of teaching mode, teaching means, will be related to the improvement of teaching quality, will bring progress and update the teaching idea and the development of the history of foreign language teaching can prove this point very well. How to grasp the relationship between modern media and foreign language teaching, so that modern media technology services in teaching, it is worth to be explored and tried from the perspective of theory and practice[1].

In English teaching if we teachers for all students by the teaching method of "one pot", it can not adapt to the learning characteristics and level of all the students, cannot satisfy their needs, which will lead to the outstanding students in class teaching for "food", make its potential can be difficult to get sufficient play. Backward students is due to "do not eat", and add to their learning burden and psychological burden, so that the learning enthusiasm of hit and lead to learning "left behind". This will not only affect the majority of students learning English interest and enthusiasm, but also will lead to some of the students' potential and plasticity in virtually destroyed, so that the effectiveness of English teaching greatly reduced. In order to meet the needs of different levels of students learning English, so that every student can feel the joy of learning English in varying degrees, enhance each student's self-confidence in learning english. The implementation method of 
"hierarchical teaching" is based on the requirements of the new English curriculum for students of different levels of students.

\section{The particularity of the students in our school}

Our school is located in the urban fringe, the complex structure of students. The parents of the students in many migrant workers[2], laid-off workers, self-employed households and half of the farmers in the city, and most of the family income is relatively low, the difficulties of life. Due to various reasons caused many parents of students learning attention degree is not enough, although some attention to students' learning but the improper methods, coupled with every one of the students living and studying social environment and family environment. Due to the level of knowledge and learning students in the same class is uneven. And the overall quality of students is relatively low. This has put forward higher request to the teaching work, especially the English teaching work. In English Teaching in junior high school, some students contact for a period of time for middle school English, junior high school English is much more difficult than that of primary school English, more demanding, there are more difficulties in learning, there is no curiosity and freshness of English, lose interest and confidence in learning English; although there are still some students often do not finish the homework, after-school review, but still has some potential and plasticity, but the self management ability, bad learning habits, most parents rarely cooperate with the teacher learning for their children to supervise, they believe that the academic achievement of their children is good or bad is about the school and teachers, has nothing to do with them this makes these, the potential of the students can not fully play out. These all give us to complete the teaching task, realize the teaching goal, has brought all sorts of difficulties.

According to such situation, coupled with the current teaching class is large, the number of students too much, obvious individual differences of students, junior students, and the limited teaching time, teachers could not take care of every student, and after class to communicate with the students don't have much time, emotional connection by this will be weakened, which not only makes confused the psychological needs of minority students difficult to meet the needs, and they will feel snubbed by teachers, for a long time down, these students' learning enthusiasm will disappeared, thereby affecting the classroom atmosphere, make classroom teaching cannot be successfully and effectively carried out, this to teacher's teaching and students' learning and growth are extremely unfavorable. In order to change the unfavorable situation, in many years of high school English teaching practice, and try to explore the teaching method of "teaching", and received a good teaching effect.

"Stratified teaching", namely maintaining the original natural class, according to the test results and some other formative assessment as the basis, a class of students will be divided into A, B, C three levels. Hierarchical teaching is actually in progress as the prerequisite, the level of competition as a means, counseling, focusing on goal as the core of a kind of education, teaching methods. It is based on teaching content, teaching methods, teaching object, teaching process research, to target classification is based, to form the evaluation as a driving force, give full play to the guiding role of teachers, to mobilize the enthusiasm of students learning, emphasis on learning gains and personality development. Let every student can feel the joy of success in learning in different degree, enhance the self-confidence of students in learning English, improve their English learning enthusiasm and initiative, will eventually learn to, learn the purpose of the English teaching task smoothly and efficiently completed, thereby improving the quality of English Teaching in large area[3].

\section{The implementation process and measures of Stratified Teaching}

From the first day of a school, is according to the students' academic performance and student of English learning confidence, perseverance, and interest, intelligence level and inherent potential to divide the level of students and 12 students were selected as group A (higher levels), pick 22 for group B (secondary level), group C (basic level) in the remaining 12. At the same time, do a good 
job of students' ideological work, help them to correctly deal with the level of division, to establish self-confidence and consistent attitude to learn, and constantly overcome self, improve the self.

The level of division is not static, but a dynamic division. A general upgrade per month, general qualified students to a level. Total score out of 100 points, the classroom performance points accounted for $20 \%$, accounting for $30 \%$, unit test accounted for $10 \%$, the monthly test accounted for $40 \%$, the monthly test is also divided into written and oral, written examination accounted for $20 \%$, oral accounting for $20 \%$. For example: a C group of students, review of qualified, can enter the B group,

Then you can gradually upgrade. This approach has changed the past that only pay attention to the final results of the evaluation method does not pay attention to the process. Teachers in the teaching process, students can always pay attention to changes, and according to the specific situation at any time to conduct individual counseling, so that their learning interest and performance continues to rise. This objective is to better the students learning process guidance, once a problem is found, timely analysis of the adjustment, prevent the students left behind, but also easy to students according to their own cognitive characteristics of their learning progress and shortcomings of understanding and reflection, and improvements in a timely manner and actively explore suitable for their own learning methods. So that they can take the initiative development, all-round development, positive, in order to maintain and consolidate the learning interest of the students, let students correct understanding of themselves, are evaluated on the basis of their, and realize the rise and drop in a great extent depending on their efforts at ordinary times, rather than rely on temporary luck or a moment of effort. This makes them feel pressure, and pressure as the driving force, in the usual competition to make progress, seek development. Mobilize every student's interest, enthusiasm, initiative and initiative in learning english[4].

\section{Implementation effect of Stratified Teaching}

After the implementation of the hierarchical teaching, students of the same level are in the same starting line, feeling almost horizontal, especially the poor foundation of students, to overcome the past that kind of inferiority complex, to re-establish the confidence to learn English well. Students answer the teacher's question is dying, very active classroom atmosphere, a group of students in the face of strong opponents is not like the past so careless, past that blind complacent, arrogant superior

Feeling dismissed, because a little careless, they also have the risk of being downgraded. In this way, the pressure becomes a force. B group of students feel that learning has received, and tasted the sweetness of learning English, learning English enthusiasm up, change the past that kind of "want me to learn" to "I want to learn" the passive situation. C group of students also feel it has been paid more attention to, is no longer a forgotten corner, also have interest in English, most students showed a tendency to active learning, such as: some students are able to take the initiative to ask the word spelling, on time back phrases, sentences and dialogue, have even in advance. Due to the adoption of the upgrade system, also launched a competition between different levels, the English learning atmosphere is very strong. After a period of experiment, I teach classes in class time I go to class, the other time hardly go to class, from the family conditions, parents are both college and undergraduate is 5 , accounting for $10.86 \%$; one of the parents is a college, the other party is graduated from school 1 name, account for $2.17 \%$; both parents graduated from high school has 5 students, accounting for $10.86 \%$; one of the parents of junior high school, the other party is a high school graduate has 11 , accounting for $23.91 \%$; both parents graduated from junior high school has 11 students, accounting for $23.91 \%$; one of the parents of junior high school graduation, the other side is a high school graduate has 3 , accounting for $6.52 \%$; one of the parents of junior high school, the other party is a primary school in 5, accounting for $10.86 \%$; both parents are primary school graduated 2 students, accounting for $4.35 \%$. Most students' parents do not have the ability to tutor students, but also the strength of the tutor. But the results of this class is always in a steady upward trend. A group of students from the original 10, increased to 20 of present; $C$ group of students also reduced the two of which a student by the beginning of the 28 points, to now, 78 
minutes; which last year, the class of rank and the average score on the original nine classes in the fifth ranked second place at present; score in narrowing, excellent rate of is also on the rise. Especially in recent tests, the birth rate is higher than class three, class two, class six and class seven. Class three, class two, class six and class seven, which were tested from last year, are two classes of students who are in the class together. Nine classes no points. Hierarchical teaching is not only to reduce the academic burden on students, the development of students' personality, mobilize the enthusiasm of students learning, the different levels of students to clear their learning needs and goals, and in learning help each other, to overcome the difficulty of common improve, but also the formation of the[5]

Effective learning strategies, and lay a solid foundation for their lifelong learning and development.

\section{Conclusion}

Learning English and learning other courses, relying solely on the explain of classroom teachers and some practice, not by doing homework independently, students are difficult to obtain solid knowledge and skills, skills. In the daily study and life, different levels of students is often unified tired a lot of homework, the students with good grades will feel some homework simply not necessary and not do it; the poor performance of the students because of that some homework is too difficult, do and don't do; teachers but because they did not finish the homework on time and unhappy. Then the face of multiple levels of students, how to use the work to consolidate the knowledge, training skills, intellectual development, expand knowledge? In this regard, in hierarchical teaching, in addition to the hierarchical content, homework also conducted a stratified, but homework different in class, homework quantity can not be too much, not too little, but can not be too simple or too easy easy to moderate, how much should be moderate. So teachers should start from the actual situation of the students and individual differences, according to the characteristics of students at different levels and the subject taught, in a certain range, in addition to the use of materials matching exercises, teachers have a definite object in view to press, and three levels to design assignments, each student can get optimal consolidation development. Homework is not only used to check and measure of a class, the students listening effect, more students to consolidate what they have learnt in class an important means and ways of knowledge and leak fill a vacancy. For example: in lesson 46, I found the ABC Group in some of my classmates have different level exists some problems, group C dialogue students didn't read well, let them after class reading fluent after recording; group B some schoolmates repeat is not ideal, let they after repeat write in the job, the next day to pay up to check; a group of some students for some English speaking countries, geographical location, weather, specialty and attractions of the know very little, let them after class through tool books or the Internet to find these data, using the class before the report or unit summary to communicate. By doing so, they have not only learned the background knowledge related to the textbook, but also cultivate the ability and writing ability to find the relevant information. This is conducive not only to students to consolidate the knowledge, the skill training, develop their intelligence and expand the knowledge of a favorable surface and for teachers to check the effectiveness of teaching and guiding students' learning, adjust the teaching program also plays a important role.

Anyway, through homework exercises, different students to consolidate and deepen the new knowledge; through homework exercises to promote the formation of different students' language ability; through homework exercises to counseling, the poor students, taking into account the outstanding student, reduce the number of poor students, and comprehensively improve the quality of English teaching.

\section{References}

[1] Li Guilan et al. The new concept of EQ and non intelligence training Tibet people's Publishing House 2001.9. 
[2] Tan Zhenhua: "teaching theory of reading" social science literature press, 2000.

[3] Hu Chundong: "English teaching method", higher education press.

[4] Wang Cairen Jia Guanjie Hu Chundong, editor in chief: "foreign language educational psychology" Guangxi Education Publishing House.

[5] Liu Jianhua, editor in chief: "high school English teaching innovation" full, Academic Press. 